\title{
Differentiation of Glucose Toxicity from Beta Cell Exhaustion during the Evolution of Defective Insulin Gene Expression in the Pancreatic Islet Cell Line, HIT-T15
}

\author{
Antoinette Moran, ${ }^{\star}$ Hui-Jian Zhang, ${ }^{\ddagger}$ L. Karl Olson, ${ }^{\ddagger}$ Jamie S. Harmon, ${ }^{\ddagger}$ Vincent Poitout, ${ }^{\ddagger}$ and R. Paul Robertson ${ }^{\ddagger}$ \\ $*$ Department of Pediatrics, and ${ }^{\ddagger}$ Division of Diabetes, Endocrinology, and Metabolism, and Department of Internal Medicine, \\ University of Minnesota, Minneapolis, Minnesota 55455
}

\begin{abstract}
Chronic exposure of HIT-T15 cells to supraphysiologic glucose concentration diminishes insulin gene expression and decreased binding of two critical insulin gene transcription factors, STF-1 and RIPE-3b1 activator. To distinguish whether these changes are caused by glucose toxicity or beta cell exhaustion, HIT-T15 cells grown from passage 75 through 99 in media containing $11.1 \mathrm{mM}$ glucose were switched to $0.8 \mathrm{mM}$ glucose at passage 100 . They regained binding of STF-1 and RIPE-3b1 activator and had a partial but minimal return of insulin mRNA expression. In a second study, inclusion of somatostatin in the media-containing $11.1 \mathrm{mM}$ glucose inhibited insulin secretion; however, despite this protection against beta cell exhaustion, dramatic decreases in insulin gene expression, STF-1 and RIPE-3b1 binding, and insulin gene promoter activity still occurred. These data indicate that the glucotoxic effects caused by chronic exposure to supraphysiologic concentration of glucose are only minimally reversible and that they are not due simply to beta cell exhaustion. These observations carry with them the clinical implication that Type II diabetic patients who remain hyperglycemic for prolonged periods may have secondary glucose toxic effects on the beta cell that could lead to defective insulin gene expression and worsening of hyperglycemia. (J. Clin. Invest. 1997. 99:534539.) Key words: glucose toxicity • beta cell exhaustion • insulin gene
\end{abstract}

\section{Introduction}

We previously reported that chronic exposure of HIT-T15 cells, a beta cell line derived from simian virus 40-transformed Syrian hamster pancreatic islets (1), to high glucose concentration causes decreased insulin secretion, content, mRNA levels, and gene transcription and that these effects are prevented by culturing cells in media containing low glucose concentration $(2,3)$. This defect in transcription was associated with decreased binding of two critical insulin gene transcription factors, STF-1 (4) and RIPE-3b1 activator (5). We hypothesized

Address correspondence to R. Paul Robertson, M.D., Division of Diabetes, Endocrinology, and Metabolism, Box 101 UMHC, 516 Delaware Street SE, Minneapolis, MN 55455. Phone: 612-626-1960; FAX: 612-626-3133.

Received for publication 10 July 1996 and accepted in revised form 21 November 1996.

J. Clin. Invest.

(C) The American Society for Clinical Investigation, Inc.

0021-9738/97/02/0534/06 \$2.00

Volume 99, Number 3, February 1997, 534-539 that glucose toxicity was the mechanism for these findings. Alternatively, beta cell desensitization and/or exhaustion (6-19) might as well explain defective insulin secretion from beta cells chronically exposed to high glucose concentrations. Beta cell exhaustion is an especially attractive alternative to our interpretation of glucotoxicity in our experiments because of their chronicity. In this regard, at least two studies have shown that exposure of islets to high glucose concentrations leads to beta cell dysfunction that is preventable if insulin secretion is inhibited during the high glucose exposure (18-19).

We designed experiments to determine the extent to which glucose toxicity can be differentiated from beta cell exhaustion as a cause of beta cell dysfunction in HIT cells chronically exposed to high glucose concentrations. The two approaches were $(a)$ to switch late passage cells that had lost insulin gene expression during prolonged culture with a high glucose concentration to a low concentration of glucose, and $(b)$ to expose cells to high glucose concentration over many passages in the presence of somatostatin $(\mathrm{SRIF})^{1}$ to inhibit insulin gene expression $(20,21)$ and insulin secretion (22). Two questions were posed: (a) Can HIT cells recover STF-1 and RIPE-3b1 activator binding and the ability to express insulin mRNA and glucose-induced insulin secretion after they have been lost during prolonged passaging under conditions of a high glucose concentration?; and (b) Can STF-1 and RIPE-3b1 activator binding, insulin gene expression, and beta cell function be preserved under conditions of chronic high glucose concentrations if beta cell exhaustion is prevented by inhibition of insulin synthesis and secretion with SRIF?

\section{Methods}

Cell culture. HIT-T15 cells were routinely grown in RPMI 1640 culture medium containing $10 \% \mathrm{FBS}$, in $5 \% \mathrm{CO}_{2} / 95 \%$ air at $37^{\circ} \mathrm{C}$. Medium was changed every $48 \mathrm{~h}$ and cells were passaged once weekly after detachment using trypsin-EDTA as previously described (23). In the first study cells were cultured from passage 75 to 146 in media containing either 11.1 or $0.8 \mathrm{mM}$ glucose. A subset of these cells cultured in $11.1 \mathrm{mM}$ glucose from passage 75 on was switched at passage 100 to $0.8 \mathrm{mM}$ glucose and cultured through passage 146 . In the second study, HIT cells were continuously cultured beginning with passage 72 through 100 in four different conditions: $0.8 \mathrm{mM}$ glucose; 0.8 $\mathrm{mM}$ glucose $+10^{-6} \mathrm{mM}$ SRIF; $11.1 \mathrm{mM}$ glucose; and $11.1 \mathrm{mM}$ glucose $+10^{-6} \mathrm{mM}$ SRIF. Aliquots of cells from each passage were frozen for later use.

Insulin content and secretion studies. To assess the efficacy of SRIF in the experimental media as an inhibitor of insulin synthesis and insulin secretion over time, weekly aliquots of $5 \times 10^{5}$ cells/well were plated in duplicate in 12-well plates and subcultured for $48 \mathrm{~h}$ in

1. Abbreviations used in this paper: CAT, chlorophenicol acetyl transferase; EMSA, electrophoretic mobility shift assay; INSCAT, insulin promoter-driven CAT; RSVCAT, RSV promoter-driven CAT; SRIF, somatostatin. 
$1.5 \mathrm{ml}$ of their usual media. Media insulin concentration and cellular insulin content were then measured as previously described (23).

Additional aliquots were used to examine static insulin secretion in response to incubation in glucose concentrations ranging from 0 to $5.6 \mathrm{mM}$. These cells were studied in 12-well plates after $48 \mathrm{~h}$ subculture in $11.1 \mathrm{mM}$ glucose without SRIF (to allow full insulin responses to glucose) as previously described (23).

Northern blot and slot blot analysis of insulin $m R N A$. For measurement of mRNA levels, HIT cells frozen at $-70^{\circ}$ were thawed and allowed to recover for $1 \mathrm{wk}$ in their original respective culture conditions. Cells were then subcultured for $48 \mathrm{~h}$ in RPMI 1640 containing $11.1 \mathrm{mM}$ glucose without somatostatin by plating $5 \times 10^{6}$ cells in $60-\mathrm{mM}$ culture dishes. Cells were rinsed with PBS $(137 \mathrm{mM} \mathrm{NaCl} ; 2.7 \mathrm{mM}$ $\left.\mathrm{KCl} ; 4.3 \mathrm{mM} \mathrm{NaH}{ }_{2} \mathrm{PO}_{4} \cdot 7 \mathrm{H}_{2} \mathrm{O} ; \mathrm{pH} 7.3\right)$ and scraped in denaturing solution (4 M guanidine thiocyanate; $25 \mathrm{mM}$ sodium citrate, $\mathrm{pH} 7 ; 0.5 \%$ sarcosyl; and $0.1 \mathrm{M} 2$-mercaptoethanol). The lysed cells were sonicated for $10 \mathrm{~s}$ at $50 \%$ duty to shear chromosomal DNA. RNA was isolated according to Chomczynski et al. (24).

For Northern blot analysis, total RNA $(5-15 \mu \mathrm{g})$ was fractionated on a $1.5 \%$ agarose-formaldehyde gel and transferred to a nylon hybridization membrane $(0.22 \mu \mathrm{m}$; Micron Separations Inc., Westboro, MA) by electroblotting. The membrane was prehybridized in $50 \%$ formamide, $5 \times$ SSC, $5 \times$ Denhardt's, $50 \mathrm{mM}$ sodium phosphate, 0.1 $\mathrm{mg} / \mathrm{ml}$ salmon sperm DNA, and $0.1 \%$ SDS at $42^{\circ} \mathrm{C}$ overnight, then hybridized for $16 \mathrm{~h}$ with ${ }^{32} \mathrm{P}$-labeled Syrian hamster preproinsulin cDNA probe (25) in the same solution. The membrane was then washed three times at room temperature in $2 \times$ SSC and $0.1 \%$ SDS, then twice at $60^{\circ} \mathrm{C}$ in $0.2 \times \mathrm{SSC}$ and $0.1 \%$ SDS, then exposed to $\mathrm{x}$-ray films (model X-Omat AR; Eastman Kodak Co., Rochester, NY) for 4 to $12 \mathrm{~h}$. Under the hybridization conditions employed, the probe hybridized to a single $0.5-\mathrm{kb}$ band consistent with HIT cell preproinsulin mRNA (26).

For slot-blot analysis, total RNA $(2.5-5 \mu \mathrm{g})$ was loaded on a nylon hybridization membrane using the bio-dot apparatus (Bio Rad Labs, Hercules, CA) and the membrane was prehybridized and hybridized as described above. Membranes were stripped for $2 \mathrm{~h}$ at $75^{\circ} \mathrm{C}$ in $1 \mathrm{mM}$ Tris- $\mathrm{HCl}, \mathrm{pH} 8.0,1 \mathrm{mM}$ EDTA, $\mathrm{pH} 8.0$, and $0.1 \times$ Denhardt's, then rehybridized with ${ }^{32} \mathrm{P}$-labeled human $\beta$-actin cDNA probe to control for variations in the amount of total RNA. Insulin and $\beta$-actin mRNA were quantitated by scanning densitometry of autoradiographs.

Nuclear extracts and electrophoretic mobility shift assay (EMSA). Nuclear extracts were prepared from HIT-T15 cells as previously described (3). Double-stranded oligonucleotides to detect STF-1 binding to the human insulin gene ( -230 to -201 , CCCCTGGTTAAGACTCTAATGACCCGCTGG) and to detect RIPE3b-1 binding to the rat insulin II gene ( -126 to -101 , TGGAAACTGCAGCTTCAGCCCCTCT) were end-labeled with $\left[\alpha-{ }^{32} \mathrm{P}\right] \mathrm{dCTP}$ using the Klenow fragment of Escherichia coli DNA polymerase I. The binding reactions (10 mg extract/lane) and electrophoresis were performed as previously described (3).

Cell transfections and chloramphenicol acetyl transferase (CAT) assay. To assess insulin gene promoter activity, frozen HIT cell stocks were allowed to recover for $1 \mathrm{wk}$ in their original respective culture condition. Cells were then subcultured for $48 \mathrm{~h}$ in RPMI 1640 containing $11.1 \mathrm{mM}$ glucose without SRIF at a density of $1.5 \times 10^{6}$ cells per well in 6-well plates. The plasmid insulin promoter-driven CAT (INSCAT) contains the human insulin gene sequences -326 to +30 linked to the chloramphenicol acetyl transferase (CAT) reporter gene (3). Duplicate wells were transfected with $1.0 \mu \mathrm{g}$ of INSCAT or $0.5 \mu \mathrm{g}$ of RSV promoter-driven CAT (RSVCAT) by a liposome-mediated method (Lipofectin; GIBCO BRL, Gaithersburg, MD). All transfections and subsequent incubations were performed in $11.1 \mathrm{mM}$ glucose. Cells were rinsed with FBS-free RPMI 1640, then $1 \mathrm{ml}$ of FBS-free RPMI 1640 containing 1:4 (wt/wt) plasmid DNA to lipofectin was added to each well. Cells were incubated for $4 \mathrm{~h}$ at $37^{\circ} \mathrm{C}$, after which the transfection media was replaced by $3 \mathrm{ml}$ of RPMI $1640.48 \mathrm{~h}$ after transfection, cells were harvested and CAT activity was assayed

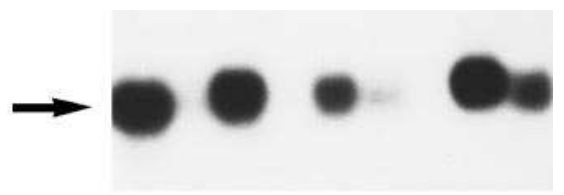

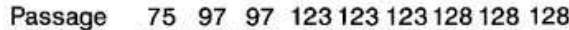

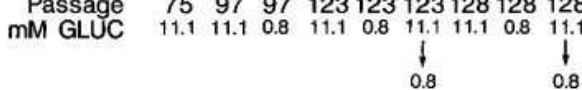

Figure 1. Northern analysis for insulin mRNA in HIT cells grown under conditions of $11.1 \mathrm{mM}$ glucose, $0.8 \mathrm{mM}$ glucose, or $11.1 \mathrm{mM}$ switched to 0.8 glucose at passage 100 .

(27). Data are presented as relative INSCAT to RSVCAT expression to control for variability in transfection efficiency observed between cells cultured in low and high glucose concentrations.

Expression of data and statistics. Data are presented as mean \pm SE. Comparisons were performed by two-sided two-sample Student's $t$ test (see Figs. 2 and 3) and by ANOVA (see Figs. 2, 4, 5, 7, and in Results under Insulin gene expression). $P<0.05$ was considered significant.

\section{Results}

Study I. Reversal of adverse effects of high glucose concentration by switching to low glucose concentration

As previously reported (2), insulin mRNA in HIT cells grown from passage 75 through 146 in RPMI containing $11.1 \mathrm{mM}$ glucose diminished progressively through passage 100 and was virtually nonexistent from passage $100-146$ ( $P<0.0001$; Figs. 1 and 2$)$. In contrast, insulin mRNA from cells grown from passage 76 through 146 in media containing $0.8 \mathrm{mM}$ glucose continued to be expressed at $70-80 \%$ of control levels. In the subset of cells that had been grown in $11.1 \mathrm{mM}$ glucose from passage 75-99 and had no insulin mRNA by passage 99, switching the glucose concentration to $0.8 \mathrm{mM}$ allowed a return of STF-1 and RIPE-3b1 activator binding (Fig. 3) as well as insulin mRNA expression to levels of $10-15 \%$ of control through passage 146 (passages $130-146 ; 11.1 \mathrm{mM}$ vs. 11.1 then $0.8 \mathrm{mM}$ glucose; $P<0.0027$; Fig. 2). However, the level of

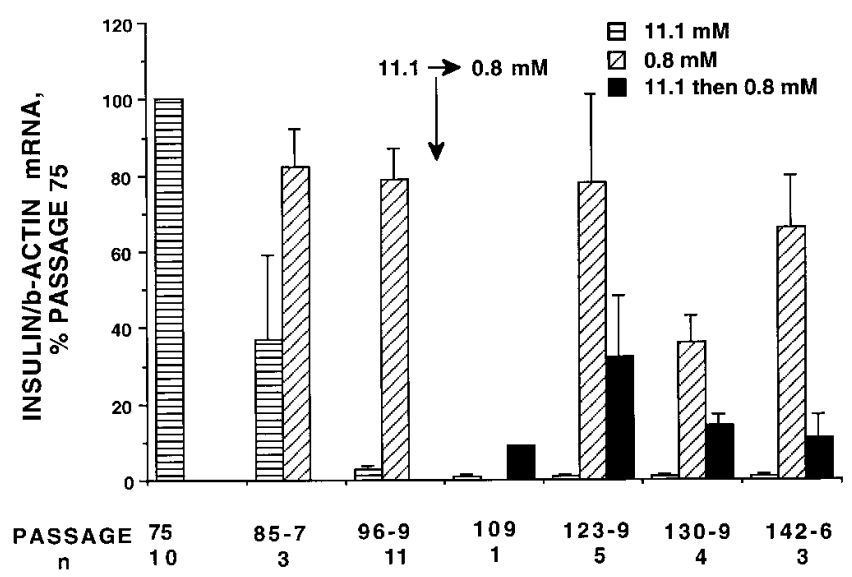

Figure 2. Illustration of disappearance of insulin mRNA in cells cultured in $11.1 \mathrm{mM}$ glucose, preservation of insulin mRNA in cells cultured in $0.8 \mathrm{mM}$ glucose, and partial restoration of insulin mRNA in cells cultured in $11.1 \mathrm{mM}$ glucose from passage 75 to 100 and then switched to $0.8 \mathrm{mM}$ glucose from passage 100 to 146 . 


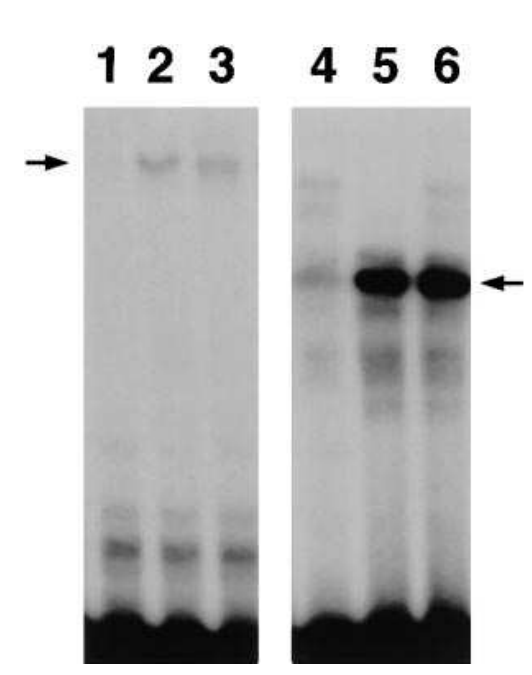

Figure 3. Electrophoretic mobility shift assay for RIPE-3b1 activator (lanes 1-3) and STF-1 (lanes 4-6) binding in HIT-T15 cells at passage 139. Lanes 1 and 4 from cells grown under conditions of 11.1 $\mathrm{mM}$ glucose; lanes 2 and 5 under conditions of $0.8 \mathrm{mM}$ glucose; and lanes 3 and 6 under conditions of $11.1 \mathrm{mM}$ switched to $0.8 \mathrm{mM}$ glucose at passage 100 . This EMSA was repeated twice more with similar results.
mRNA expression in these cells, as well as glucose-induced insulin secretion (Fig. 4), remained significantly attenuated.

\section{Study II. Cell culture with and without added SRIF}

Insulin secretion and content. Insulin concentrations in media were measured biweekly from passages $74-100$ after $48 \mathrm{~h}$ subculture in 12-well plates (Fig. 5). Insulin levels in media from cells grown in $11.1 \mathrm{mM}$ glucose without SRIF were initially fourfold higher than from cells grown in the other three conditions (passages 73-76; $P<0.0001$ ), but declined significantly over time (passages $73-6$ vs. $97-100 ; P<0.0001$ ). This finding is consistent with our previous observation that chronic exposure of HIT cells to high glucose concentration results in dramatically diminished insulin secretion (2). Media levels of insulin from the other three conditions also decreased over the same passages to a variable extent $(P=0.0443-0.005)$. Inclusion of SRIF in the media containing $11.1 \mathrm{mM}$ and $0.8 \mathrm{mM}$ glucose throughout the experiment resulted in media insulin levels similar to those of cells grown in $0.8 \mathrm{mM}$ glucose without SRIF. By passage 90 media insulin levels were equally low in cells grown in $11.1 \mathrm{mM}$ glucose with and without SRIF.

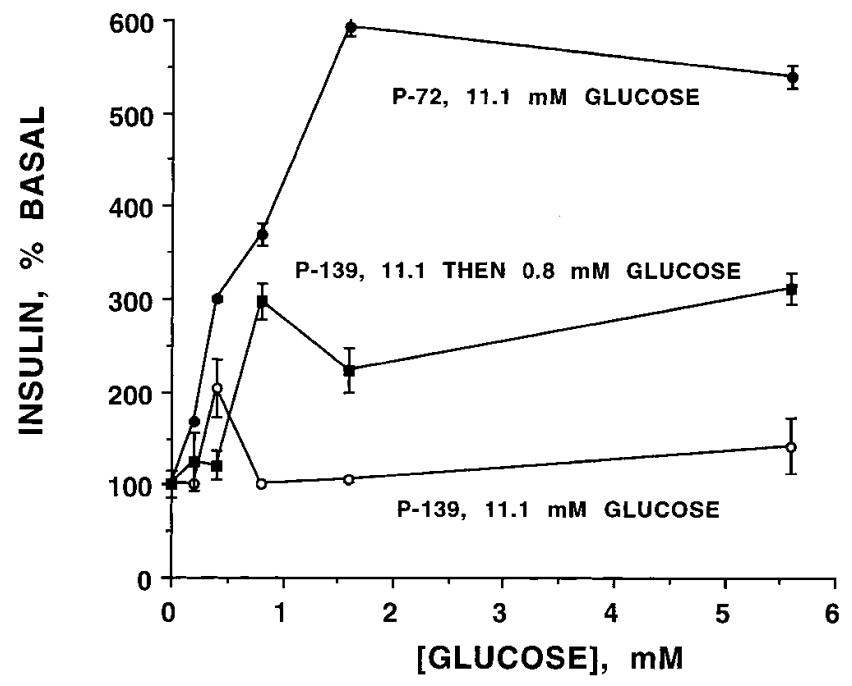

Figure 4. Insulin levels obtained after 4-h static incubations of HITT15 cells in progressively increasing concentrations of glucose for passage 72 and passage 139 cultured under conditions indicated in legend for Fig. 1. Initial insulin concentrations with no glucose in the incubation: P-72 $=549 \pm 79 ; \mathrm{P}-139(11.1 \mathrm{mM}$ glucose $)=4 \pm 0$; P-139 (11.1 switched to $0.8 \mathrm{mM}$ glucose at $\mathrm{P}-100)=5 \pm 1 ; \mu \mathrm{U} / \mathrm{mg}$ protein.

Insulin content in cells grown in $11.1 \mathrm{mM}$ glucose declined progressively over the experimental period (passages 73-6 vs. 97-100; $P<0.0001 ;$ Fig. 6). The presence of SRIF and $11.1 \mathrm{mM}$ glucose in the culture media decreased baseline insulin content compared to $11.1 \mathrm{mM}$ glucose alone (passage $73-6 ; P<0.0001$ ) and these cells cultured in SRIF underwent a similar decline in insulin content (passage $73-6$ vs. 97-100; $P=0.0007$ ). Insulin content was low initially in cells grown in $0.8 \mathrm{mM}$ glucose with and without SRIF and remained low over time.

Insulin secretion during static incubations. After 48-h subculture in $11.1 \mathrm{mM}$ glucose without SRIF, insulin secretion from cells grown under all four conditions was examined during static incubations over a range of glucose concentrations. Glucose-stimulated insulin release decreased dramatically in

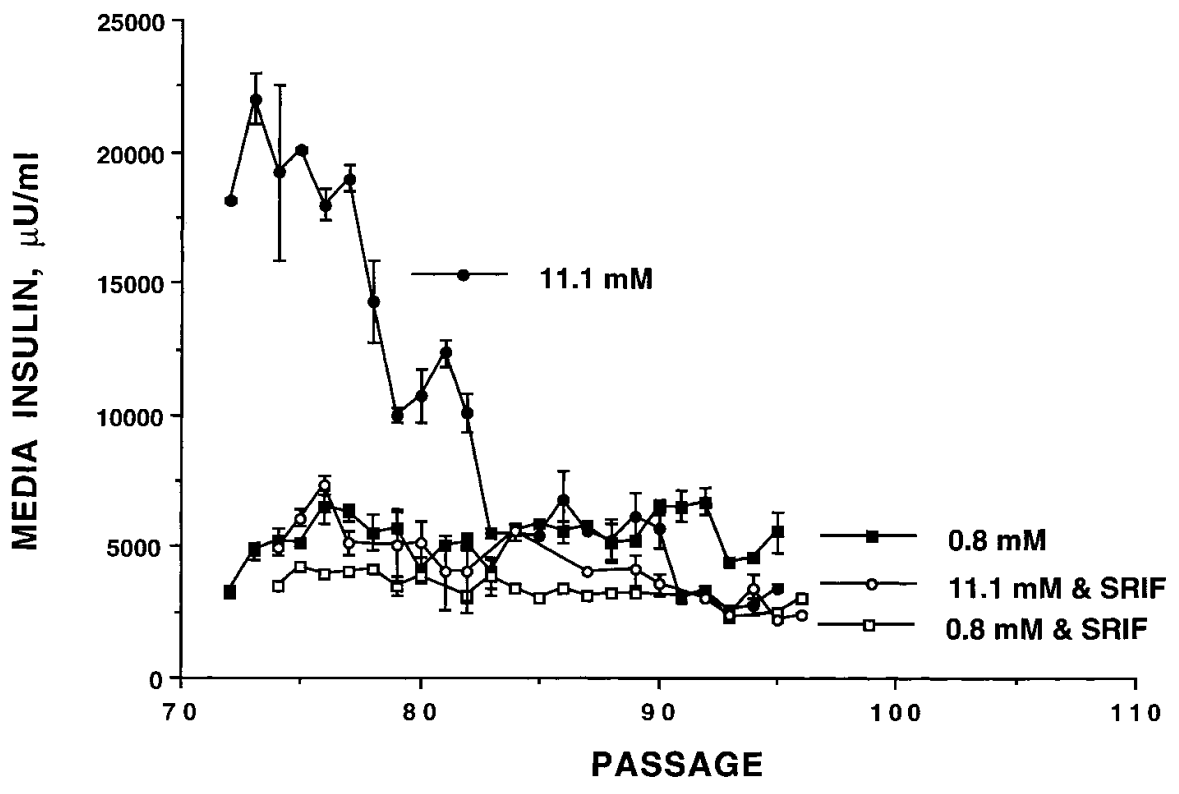

Figure 5. Media insulin levels in HIT cells from passage 74 to 100 grown in RPMI1640 medium containing $10 \%$ FCS under four conditions: $0.8 \mathrm{mM}$ glucose; $0.8 \mathrm{mM}$ glucose plus $10^{-6} \mathrm{M}$ SRIF; $11.1 \mathrm{mM}$ glucose; and $11.1 \mathrm{mM}$ glucose plus $10^{-6} \mathrm{M}$ SRIF. Each week, aliquots of cells growing under the experimental media conditions were transferred to 12 -well plates and continued in their respective experimental media. After $48 \mathrm{~h}$, media insulin concentration was determined and was normalized for protein content. 


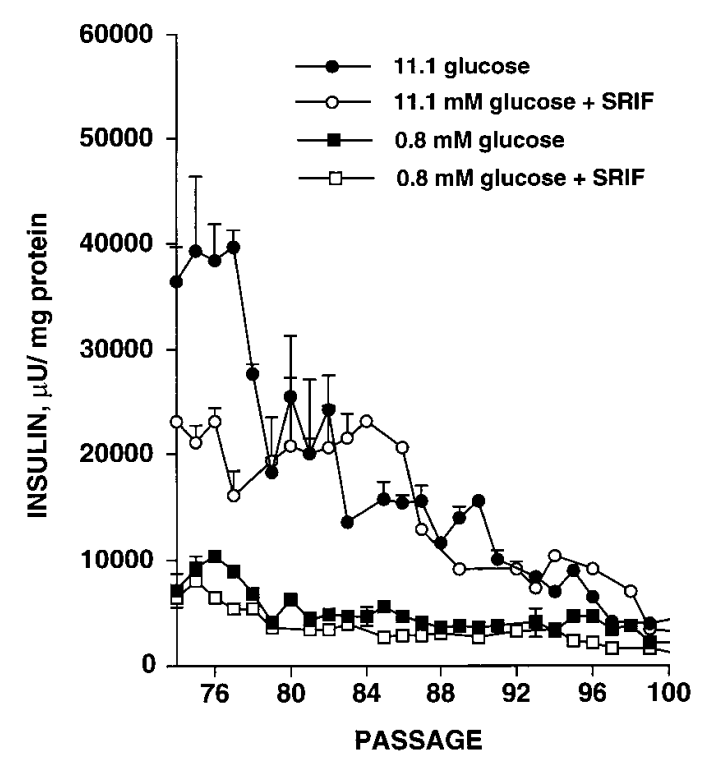

Figure 6. HIT cell insulin content in HIT cells grown under the four experimental conditions described for Fig 5. Each week, aliquots of cells growing under the experimental media conditions were transferred to 12-well plates and continued in their respective experimental media. After $48 \mathrm{~h}$, cellular insulin content was determined from acidified ethanol extracts of the cells and normalized for protein content. Inhibition of insulin secretion with SRIF did not prevent loss of insulin content in cells grown in high glucose.

cells grown in $11.1 \mathrm{mM}$ glucose as passage number increased. By passage 98-100, maximal insulin secretion in these cells was significantly less than that observed at passage 80-82 $(P<$ 0.0001 ; Fig. 7). Inclusion of SRIF in the media had no protective effect against this loss of secretion.

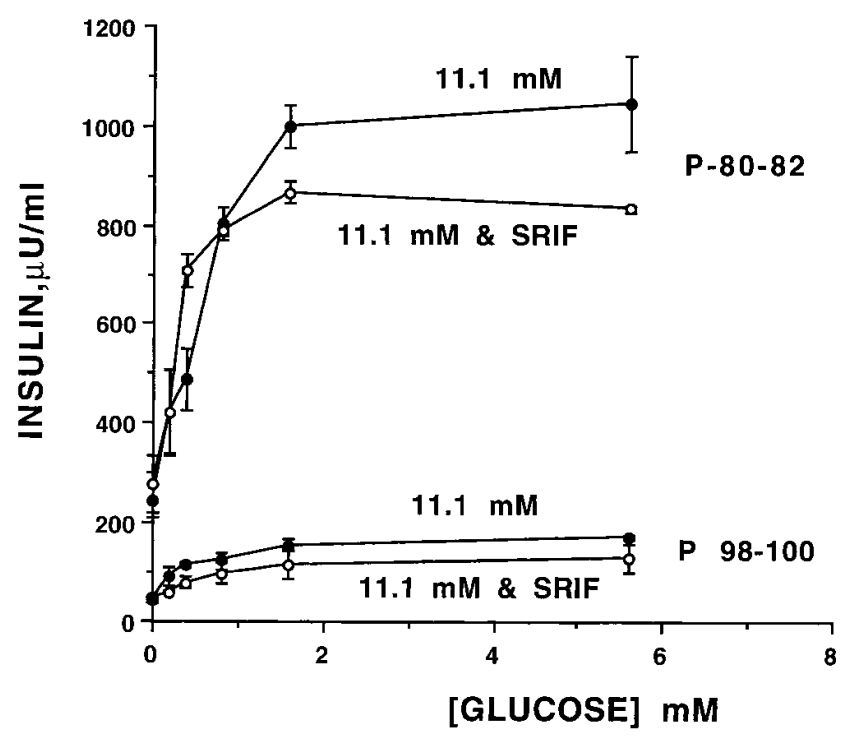

Figure 7. Insulin secretion in response to stimulation by glucose in $2 \mathrm{~h}$ static incubations with varying concentrations of glucose in KRB were performed in cells from early (passage 80 and 82) and late (passage 98 and 100) passages of cells cultured in 12-well plates after 48-h subculture in $11.1 \mathrm{mM}$ glucose in the absence of SRIF. Inhibition of chronic insulin secretion with SRIF did not prevent the loss of glucose-induced insulin secretion in late passage cells chronically cultured in high glucose concentrations.
Insulin gene expression. Insulin mRNA levels in HIT cells cultured under the four experimental conditions were compared by both Northern blot and slot blot analysis to determine whether the observed decline in insulin secretion and content in cells cultured in $11.1 \mathrm{mM}$ glucose with or without SRIF was accompanied by parallel changes in insulin gene expression. Insulin mRNA abundance was less in cells grown under high glucose conditions with and without SRIF compared to cells grown under low glucose conditions (Fig. 8.). Similar results were observed using slot blot analysis performed three separate times on passages 92, 93, and 94 wherein densitometry of insulin mRNA/ $\beta$-actin in RNA revealed a highly significant difference in cells grown in media containing 11.1 and $0.8 \mathrm{mM}$ glucose $(0.46 \pm 0.08$ vs. $0.08 \pm 0.0 ; P<0.0005)$ that persisted when cells had been grown in $11.1 \mathrm{mM}$ glucose plus SRIF vs. $0.8 \mathrm{mM}$ glucose $+\operatorname{SRIF}(0.51 \pm 0.03$ vs. $0.22 \pm 0.02$; $P=0.0018)$. Thus, preventing chronic stimulation of insulin secretion did not prevent cells grown in $11.1 \mathrm{mM}$ glucose from developing diminished insulin mRNA levels over time.

STF-1 and RIPE-3b1 activator binding and insulin gene promoter activity. EMSA revealed no evidence that SRIF by itself altered STF-1 or RIPE-3b1 activator binding (Fig. 9). Cells from the four experimental conditions transiently transfected with a CAT reporter gene driven by the $5^{\prime}$ regulatory region $(-326$ to +30$)$ of the human insulin gene were used to determine whether the decrease in insulin gene expression in cells chronically cultured in $11.1 \mathrm{mM}$ glucose with and without SRIF was accompanied by parallel changes in insulin gene promoter activity (Fig. 10). The relative expression of INSCAT to RSVCAT activity was not different in passages 92-94 of HIT cells cultured in $0.8 \mathrm{mM}$ glucose with or without SRIF. In contrast, relative expression of INSCAT to RSVCAT activity in HIT cells cultured in $11.1 \mathrm{mM}$ glucose with or without SRIF was markedly reduced in passages 92-94 compared to their counterparts cultured under $0.8 \mathrm{mM}$ glucose conditions $(P=$ $0.0153,0.0141)$. These data indicate that the $\sim 70 \%$ decrease in insulin gene promoter activity found in HIT cells chronically cultured in $11.1 \mathrm{mM}$ glucose could not be prevented by protecting them against chronic stimulation of beta cell secretion with SRIF.

\section{Discussion}

These studies were performed to determine whether glucotoxic effects on insulin gene expression caused by prolonged culturing of HIT cells in supraphysiologic concentrations of glucose are reversible and to differentiate glucose toxicity

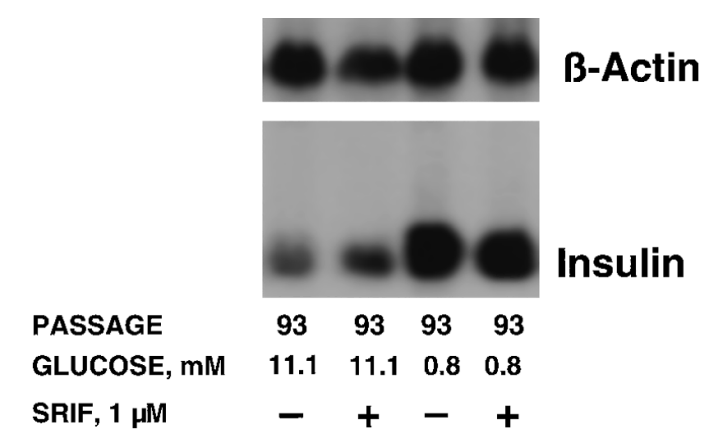

Figure 8. Analysis of mRNA levels in late passage HIT cells (passage 93) grown under the four experimental conditions described in Fig. 5. 


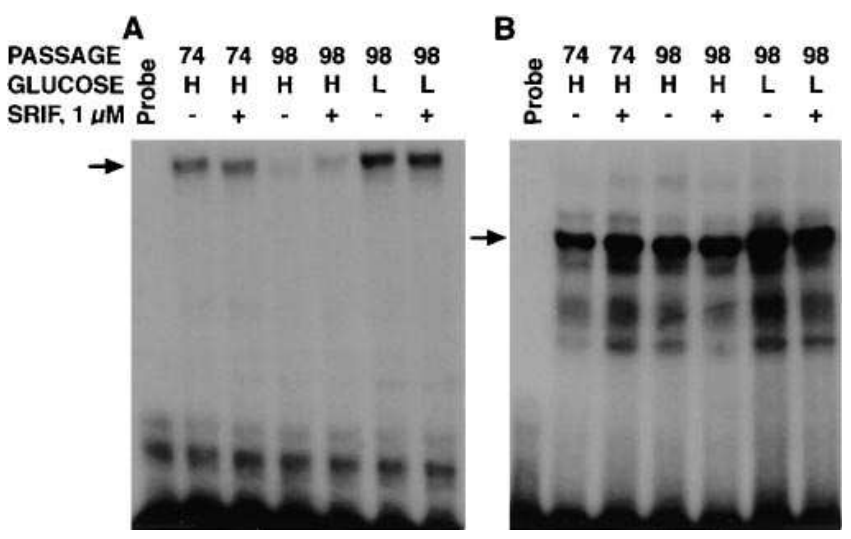

Figure 9. Electrophoretic mobility shift assay for RIPE-3b1 activator $(A)$ and STF-1 $(B)$ binding in HIT-T15 cells at passage 74 treated for $48 \mathrm{~h}$ with or without $10^{-6} \mathrm{M}$ SRIF and passage 98 chronically cultured in media containing 0.8 or $11.1 \mathrm{mM}$ glucose with or without $10^{-6} \mathrm{M}$ SRIF. $\mathrm{H}=11.1 \mathrm{mM}$ glucose and $\mathrm{L}=0.8 \mathrm{mM}$ glucose in culture media.

from beta cell exhaustion as mechanisms of action for decreased insulin synthesis and secretion. The data reported herein indicate that the glucotoxic phenomenon we have observed is partially but minimally reversible by switching glucose in the culture media from a high to a low concentration after insulin gene expression has been lost. They also indicate that these glucotoxic events are not due simply to beta cell exhaustion because inclusion of somatostatin to prevent glucose-stimulated insulin secretion during chronic culture with supraphysiologic glucose concentrations did not prevent loss of insulin gene expression.

The rationale for performing these studies began with the initial observation that prolonged culturing of HIT cells in media containing $11.1 \mathrm{mM}$ glucose lost the ability to express insulin mRNA $(2,3)$. We demonstrated that this loss in insulin gene expression was not observed during prolonged culturing in media containing $0.8 \mathrm{mM}$ glucose which is a more physiologic concentration for HIT cells $(2,23)$. This low glucose concentration is slightly stimulatory for insulin secretion because the glucose dose-insulin response curve in HIT cells is shifted leftward such that the $\mathrm{EC}_{50}$ is less than $2 \mathrm{mM}$ (23). The loss of insulin gene expression observed when culturing with $11.1 \mathrm{mM}$ glucose was associated with a marked reduction in insulin promoter activity and decreased binding of two critical insulin gene transcription factors, STF-1, and RIPE-3b1 activator (4, 5). We demonstrated that these two transcription factors are important in the HIT cell because mutation of the enhancer-

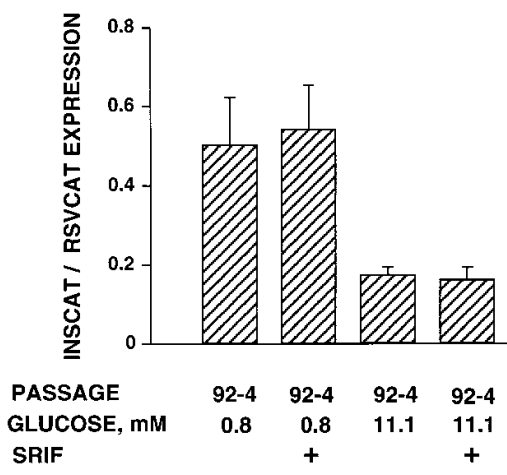

Figure 10. CAT activity in late passage HIT cells (passages 92-94) cultured under the four experimental conditions described in Fig 5 . Data represent the mean of the relative expressions of INSCAT to RSVCAT for four independent experiments with duplicate observations $(n=4)$. promoter portion of the insulin gene to which these factors bind caused marked decreases in insulin gene expression (3, 4). While searching for a mechanism for these events we observed that STF-1 gene transcription was unaffected judging from nuclear run-on experiments. However, Northern analysis for STF-1 gene expression indicated a possible posttranscriptional defect because there was accumulation of immature STF-1 RNA and an absence of STF-1 mRNA (4). Recently, similar findings have been reported in an unrelated cell line, $\beta$ TC-6, which were accompanied by loss of RIPE-3b1 activator but not STF-1 (28).

Although we have published data indicating that insulin gene expression can be preserved in HIT cells by using media containing physiologic glucose concentrations, an important alternative interpretation is that this glucose concentration was simply selective for an insulin responsive clone(s) of cells. It has been our opinion that this was not a likely explanation because no differences have been observed in levels of glucose transporter (GLUT-2), glucokinase mRNA or activity, population doubling times, or RFLP pattern when comparing HIT cells grown under high vs. low glucose conditions (2), nor could we reproduce these changes by culturing cells in an $11.1 \mathrm{mM}$ concentration of mannitol with a low concentration of glucose $(0.8 \mathrm{mM})$. The new data provided in this manuscript that we are able to partially, albeit minimally, restore lost insulin gene expression by switching the cells from a high to a low glucose concentration at passage 100 supports our opinion that the higher glucose concentration had not simply eliminated clones able to express the insulin gene. Otherwise, we could not have seen partial return of insulin gene expression when switching to a lower glucose concentration at passage 100. Rather, these data suggest that we were working with the same population of cells and that glucose toxicity induced by conditions we have studied could be partially reversed. Nonetheless, the resolution of this issue of cell selection vs. glucotoxic effect on existing cells can only come from in vivo models wherein the potentially adverse effects of chronic hyperglycemia on insulin gene expression can be examined. To this end, we have begun studies of the consequences of spontaneous hyperglycemia on STF-1 and RIPE-3b1 activator binding as well as insulin gene expression in Zucker diabetic fatty rats.

The theories of glucose desensitization and beta cell exhaustion have been important to understanding insulin secretory dynamics of cells exposed to high concentrations of glucose for varied periods of times. Most of these experiments (6-19) have involved pancreatic islets exposed in vitro or animals exposed in vivo to high glucose concentrations for periods of days or several weeks. Evidence for beta cell exhaustion was provided by Sako et al. (18) who induced hyperglycemia in normal rats for $48 \mathrm{~h}$ with or without the presence of diazoxide (an inhibitor of insulin secretion which acts at the ATP-sensitive $\mathrm{K}^{+}$channel). The animals were subsequently killed and beta cell function was studied using a perifusion method. Hyperglycemia was associated with a reduction in the acute insulin secretory response to glucose which did not occur in islets from animals whose 48-h insulin secretion had been inhibited by diazoxide. The authors concluded that preventing protracted glucose-induced insulin secretion protected the beta cells from the deleterious effects of hyperglycemia and, thus, that excessive stimulation of insulin secretion rather than glucose toxicity or glucose desensitization caused beta cell dysfunction. Similarly, Leahy et al. (19) found that diazoxide par- 
tially blocked the fall in glucose-induced insulin secretion usually seen in rats $2-3$ wk after partial pancreatectomy, suggesting that the strain of maintaining adequate insulin secretion when beta cell mass is reduced leads to exhaustion of the cells. These experimental examples verify that the concept of beta cell exhaustion is an important one and not one that our data refute. Nonetheless, because inclusion of somatostatin markedly inhibited glucose-induced insulin secretion under our experimental conditions and yet failed to protect HIT cells from losing insulin gene expression, the phenomenon we have studied can be clearly differentiated from beta cell exhaustion. Had beta cell exhaustion been the explanation for our results, prevention of insulin secretion by somatostatin would have protected HIT cells grown in $11.1 \mathrm{mM}$ glucose and preserved insulin gene expression (29).

In conclusion, we have demonstrated that the glucose toxic effect induced by prolonged culturing of HIT cells in supraphysiologic concentration of glucose is not only preventable by culturing these cells in a low concentration of glucose, but also is partially reversible by switching late passage cells that have lost insulin gene expression to low concentrations of glucose. Moreover, the evolution of this defect in insulin gene expression persists despite including somatostatin in the cultures which inhibited glucose-induced insulin secretion. Thus, these experiments differentiated glucose toxicity from beta cell exhaustion and point to the former as the mechanism for defective insulin gene expression. Interestingly, a minor component of insulin gene transcription returned after switching our cells to a low glucose media at passage 100 . We interpret this to mean that a small component of glucose desensitization and/or beta cell exhaustion was also present because the terms "desensitization" and "exhaustion" imply reversible phenomena whereas "toxicity" implies damage and irreversibility (29). These observations carry with them important clinical implications for Type II diabetes mellitus because patients with this disease commonly live for many years in a state of only partially corrected, constant hyperglycemia which may have secondary glucose toxic effects on the beta cell that could potentially cause defective insulin gene expression and worsening of the disease.

\section{Acknowledgments}

We gratefully acknowledge the excellent technical assistance of Ms. Elizabeth Oseid, statistical assistance from Will Thomas, Ph.D., and the superb secretarial services of Ms. Lucy Mittag.

This work was supported by National Institutes of Health Grant R01-DK-38325.

\section{References}

1. Santerre, R.F., R.A. Cook, R.M.D. Crisel, J.D. Sharp, R.J. Schmidt, D.C. Williams, and C.P. Wilson. 1981. Insulin synthesis in a clonal cell line of simian virus 40 -transformed hamster pancreatic $\beta$-cells. Proc. Natl. Acad. Sci. USA. 78: 4339-4343.

2. Robertson, R.P., H.-J. Zhang, K.L. Pysdrowski, and T.F. Walseth. 1992. Preservation of insulin mRNA levels and insulin secretion in HIT cells by avoidance of chronic exposure to high glucose concentrations. J. Clin. Invest. 90:320-325.

3. Olson, L.K., J.B. Redmon, H.C. Towle, and R.P. Robertson. 1993. Chronic exposure of HIT cells to high glucose concentrations paradoxically decreases insulin gene transcription and alters binding of insulin gene regulatory protein. J. Clin. Invest. 92:514-519.

4. Olson, L.K., A. Sharma, M. Peshavaria, C.V.E. Wright, H.C. Towle, R.P.
Robertson, and R. Stein. 1995. Reduction of insulin gene transcription in HITT15 cells chronically exposed to a supraphysiologic glucose concentration is associated with loss of STF-1 transcription factor expression. Proc. Natl. Acad. Sci. USA. 92:9127-9131.

5. Sharma, A., L.K. Olson, R.P. Robertson, and R. Stein. 1995. The reduction of insulin gene transcription in HIT-T15 $\beta$ cells chronically exposed to high glucose concentration is associated with the loss of RIPE3b1 and STF-1 transcription factor expression. Mol. Endocrinol. 9:1127-1134.

6. Vague, P., and J.P. Moulin. 1982. The defective glucose sensitivity of the $\beta$-cell in noninsulin-dependent diabetes: improvement after twenty hours normoglycaemia. Metab. Clin. Exp. 31:139-142.

7. Unger, R.H., and S. Grundy. 1985. Hyperglycaemia as an inducer as well as a consequence of impaired islet cell function and insulin resistance: implications for the management of diabetes. Diabetologia. 28:119-121.

8. Imamura, T., M. Koffler, J.H. Helderman, D. Prince, R. Thirlby, L. Inman, and R.H. Unger. 1988. Severe diabetes induced in subtotally depancreatized dogs by sustained hyperglycemia. Diabetes. 37:600-609.

9. Robertson, R.P. 1989. Type II diabetes, glucose "nonsense," and islet desensitization. Diabetes. 38:1501-1505.

10. Giroix, M-H, P. Serradas, and B. Portha. 1989. The desensitization of normal $\beta$-cells to glucose in vitro is transient and not related to high glucose levels. Endocrinology. 125:1999-2007.

11. Rossetti, L., A. Giaccari, and R. DeFronzo. 1990. Glucose toxicity. Diabetes Care. 13:610-630.

12. Davalli, A.M., C. Ricordi, C. Socci, S. Braghi, F. Bertuzzi, B. Fattor, V. DiCarlo, A.E. Pontiroli, and G. Pozza. 1991. Abnormal sensitivity to glucose of human islets cultured in a high glucose medium: partial reversibility after an additional culture in a normal glucose medium. J. Clin. Endocrinol. Metab. 72: 202-208.

13. Yki-Järvinen, H. 1992. Glucose toxicity. Endocrinol. Rev. 13:415-431.

14. Simonson, D.C., L. Rossetti, A. Giaccari, and R.A. DeFronzo. 1992. Glucose toxicity. In International Textbook of Diabetes Mellitus. K.G. Alberti, R.A. DeFronzo, H. Keen, and P. Zimmet, editors. John Wiley \& Sons, New York. 635-667.

15. Eizirik, D.L., G.S. Korbutt, and C. Hellerström. 1992. Prolonged exposure of human pancreatic islets to high glucose concentrations in vitro impairs the $\beta$-cell function. J. Clin. Invest. 90:1263-1268.

16. Hoenig, M., L.C. MacGregor, and F.M. Matschinsky. 1986. In vitro exhaustion of pancreatic $\beta$-cells. Am. J. Physiol. 250:E502-511.

17. Kaiser, N., A.P. Corcos, I. Sarel, and E. Cerasi. 1991. Monolayer culture of adult rat pancreatic islets on extracellular matrix: modulation of $\beta$-cell function by chronic exposure to high glucose. Endocrinology. 129:2067-2076.

18. Sako, Y., and V.E. Grill. 1990. Coupling of $\beta$-cell desensitization by hyperglycemia to excessive stimulation and circulating insulin in glucose-infused rats. Diabetes. 39:1580-1583.

19. Leahy, J.L., L.M. Bumbalo, and C. Chen. 1994. Diazoxide causes recovery of $\beta$-cell glucose responsiveness in $90 \%$ pancreatectomized diabetic rats. Diabetes. 43:173-179.

20. Zhang, H.-J., J.B. Redmon, J.M. Andresen, and R.P. Robertson. 1991 Somatostatin and epinephrine decrease insulin messenger ribonucleic acid in HIT cells through a pertussis toxin-sensitive mechanism. Endocrinology. 129: 2409-2414.

21. Redmon, J.B., H.C. Towle, and R.P. Robertson. 1994. Regulation of human insulin gene transcription by glucose, epinephrine, and somatostatin. Diabetes. 43:546-551.

22. Robertson, R.P., P. Tsai, S.A. Little, H.-J. Zhang, and T.F. Walseth. 1987. Receptor-mediated adenylate cyclase-coupled mechanism for PGE $_{2}$ inhibition of insulin secretion in HIT cells. Diabetes. 36:1047-1053.

23. Zhang, H.-J., T.F. Walseth, and R.P. Robertson. 1989. Insulin secretion and cAMP metabolism in HIT cells. Reciprocal and serial passage-dependent relationships. Diabetes. 38:44-48.

24. Chomczynski, P., and N. Sachi. 1987. Single-step method of RNA isolation by acid guanidium thiocyanate-phenol-chloroform extraction. Anal. Biochem. 162:156-159.

25. Bell, G.I., and R. Sanchez-Pescador. 1984. Sequence of a cDNA encoding Syrian hamster preproinsulin. Diabetes. 33:297-300.

26. Hammonds, P., P.N. Schofield, and S.J.H. Ashcroft. 1987. Glucose regulates preproinsulin messenger RNA levels in a clonal cell line of simian virus 40-transformed $\beta$ cells. FEBS Lett. 213:149-154.

27. Kingston, R.E., and J. Sheen. 1991. Introduction of DNA into mammalian cells. In Current Protocols in Molecular Biology. F. Ausubel, R. Brent, R.E. Kingston, D.D. Moore, J.D. Seidman, J.A. Smith, and K. Struhl, editors. Greene Publishing Associates and Wiley Interscience, New York. 901-996.

28. Poitout, V., L.K. Olson, and R.P. Robertson. 1996. Chronic exposure of $\beta$ TC- 6 cells to supraphysiologic concentrations of glucose decreases binding of the RIPE3b1 insulin gene transcription activator. J. Clin. Invest. 97:1041-1046.

29. Robertson, R.P., L.K. Olson, and H.-J. Zhang. 1994. Differentiating glucose toxicity from glucose desensitization: a new message from the insulin gene. Diabetes. 43:1085-1089. 